\title{
Information Systems' Diverse Origins Coming Together
}

\author{
Anthony Scime \\ The College at Brockport, \\ State University of New York, \\ Brockport, NY, USA \\ ascime@brockport.edu \\ Charles Bush \\ The College at Brockport, \\ State University of New York, \\ Brockport, NY, USA
}

\author{
Francis Kofi Andoh-Baidoo \\ University of Texas - \\ Pan American, Edinburg, \\ TX, USA
}

andohbaidoof@utpa.edu

\author{
Babajide Osatuyi \\ New Jersey Institute of \\ Technology, Newark, \\ NJ, USA
}

$$
\text { cbush@brockport.edu }
$$

\section{bjo4@njit.edu}

\section{Executive Summary}

The diversity of IS programs and research has been of interest to various professions. It has been argued that IS has developed to the extent where it does not have to rely on other reference disciplines, but should rather serve as a reference discipline for other disciplines. While IS may have developed its own discipline, its location in different academic units may influence the venue of faculty publications. The understanding of the relationships between venue of publication and location of IS programs will influence curriculum development especially at the doctoral level and inform faculty placement decisions. In this paper, we examine IS research that falls into the professional categories of business, engineering, education, and library science for faculty from information systems programs. We examined the research publications of the faculty from the twenty-four IS programs accredited by ABET Inc. The data shows that irrespective of the location of the IS program, over 50\% of the faculty publications are in the Engineering venue. Further, the results indicate that the location of the IS program influences the publication venue. We also suggest that the tenure and promotion requirements also influence the venue of the publications of IS faculty. Our research contributes to both professional practice and scholarly research. In academia, we suggest that the interest of the faculty may influence their employment locations and research venues.

Material published as part of this publication, either on-line or in print, is copyrighted by the Informing Science Institute. Permission to make digital or paper copy of part or all of these works for personal or classroom use is granted without fee provided that the copies are not made or distributed for profit or commercial advantage AND that copies 1) bear this notice in full and 2) give the full citation on the first page. It is permissible to abstract these works so long as credit is given. To copy in all other cases or to republish or to post on a server or to redistribute to lists requires specific permission and payment of a fee. Contact Publisher@InformingScience.org to request redistribution permission.
Keywords: IS research, IS discipline, Education, IS programs, Research venues, ABET, program location

\section{Introduction}

Information, to be a useful organizational resource, must be structured for easy storage and retrieval. The information systems (IS) discipline deals with 
this resource and its related technology for the analysis, construction, deployment, use, evaluation, evolution, and management of computing artifacts in organizational settings (Madnick, 1992; Orlikowski \& Barley, 2001). Long before information systems were automated, the realm of information collection, storage, and retrieval fell to librarians. The use of information in decision making is in the purview of business. Decisions are made, based on the information available, to move an organization closer to its goals. Often information needed to make decisions must be transformed into an understandable format. Today, the transformation of information can be quite complex, requiring an engineering approach in design and implementation. As a result, IS programs teach and research in one or more of the following areas: provide information services (library science), use information systems in organizations (business), or develop hardware and/or software (engineering) (Freeman \& Aspray, 1999).

Added to the unique intersection of disciplines to form information systems, some faculty in all disciplines are concerned with how best to educate students (Aytes \& Beachboard, 2007). Research in pedagogy and curriculums are especially important in new disciplines such as information systems. In IS, a number of professional societies and the IS faculty who are members have developed and published model curricula (Scime, 2001).

Because of this diversity of origins, education and research in information systems occurs in different schools at different universities. The focus of education and research can vary as well. Business schools emphasize the efficient and effective use of organizational resources including information resources. On the other hand, technology, engineering, science, computing, and even arts and sciences schools associate IS with other computing disciplines. Here, the context of information systems is the algorithmic processes within a mathematical and engineering framework (Scime, 2002). A number of IS programs have originated in library science schools as well (Mitchell, Ford, Kraft, \& Talburt, 2003), where the emphasis is on the collection, organization, preservation, and dissemination of information resources.

As a result, IS programs can be found in Colleges of Business, Arts and Sciences, Technology, Engineering, Science, Library Science, or Computing (Cohen, 1999). The program names may vary from Business Information Systems through Computer Information Systems, Information Science, Information Resources Management, Information Technology Systems, to Management Information Systems; or may simply be Information Systems (Davis, Gorgone, Couger, Fienstein, \& Longnecker, 1997; Myers \& Beise, 1999). Even with different schools calling programs by different names and housing them in different places, most IS programs teach and research in one or more of the following areas: develop hardware or software, maintain information systems in organizations, or provide information services (Freeman \& Aspray, 1999). This diversity within the discipline creates challenges for programs in the field. For example, the challenge for management originated departments is to maintain depth in technology. On the other hand, the challenge for technically originated departments is to provide a business context (Davis et al., 1997; Information Resources Management Association, 1999).

It has been argued that IS has developed to the extent that it does not have to rely on other reference disciplines but should rather serve as a reference discipline for other disciplines (Baskerville $\&$ Myers, 2002). While IS may have developed its own discipline, its location in different academic units may influence the venue of faculty publications. The purpose of this paper is to examine whether the location of the IS program influences the venue of faculty publications. This initial exploratory study focuses on ABET accredited IS programs. The IS programs are housed in different academic department and therefore serve as a useful population for this study.

To answer this question, the paper considers the origins of information systems. Then IS research products are considered and evaluated as being in a business, engineering, education, or library science paradigm. 


\section{Background}

\section{Origin of the Discipline}

Some disciplines are both academic disciplines and professional fields. A professional field is the applied application of knowledge developed in one or more theoretical disciplines (Stark \& Lattuca, 1997). Academic disciplines and professional fields have, to varying degrees, components of substantiveness, symbolic systems, syntactic structure, and value/organizational identity. These components form a structure in which the discipline creates a program of scholarship and research (Dressel \& Marcus, 1982). The program of research must lead to a complete understanding of the organization and functioning of the discipline, as well as its knowledge base and techniques (Stark \& Lattuca, 1997).

The substantive component defines the types of problems encountered and the profession's role within society. There are four roles professions fill in society- human client service, information service, production service, and creative service (Stark \& Lattuca, 1997). The human client service role involves working directly with people by providing a personal service, such as help desk and hands-on support. The information service role provides information to others, such as instruction or advice. Professions that build artifacts provide a production service, as in design and development. Professions have a creative role and provide a service by way of artistic expression or conceptualization of new artifacts and structures. Some fields work in more than one role.

A discipline's symbolic systems define the language used by the profession to communicate. Professions have two types of symbolic systems. Interpersonal symbols allow communication with others outside of the profession. This external communication is most important in human client service and decreases in importance along the continuum to conceptualization work. The other communication method is internal to the profession. This technical communication may not be understandable to the public. In IS, this includes the languages of business, engineering, and library science.

The syntactical inquiry methods used by a profession to answer or solve problems are the ways of inquiry. These are the paradigms that define the collection, organization, and analysis of data. Within IS, inquiry is performed by methods developed in disciplines such as business, engineering, and library science.

Concerns of professional identity and ethics are the values of the discipline. These values express the relationship of a profession to society and define the functioning of the profession. The relationship to itself concerns the importance of professional organizations to the individual professional's success in the profession (Stark \& Lattuca, 1997). Connection to the professional community is strongest in professions that have government regulation or formal organizations. IS has a number of professional societies (Association of American Colleges, 1992; Scime, 2001).

IS has all the characteristics of a profession. The founding disciplines of IS are business, engineering (Denning, 1998; Freeman \& Aspray, 1999; Myers \& Beise, 1999; Watson, Taylor, Higgins, Kadlec, \& Meeks, 1999), and library science (Lindsay, 2000; Mitchell et al., 2003). IS provides technical service by building, maintaining, and managing software systems. The symbolic systems used for discourse in the IS community revolve around mathematical and graphical modeling (DFD, ERD, and UML), programming languages, digital logic, and machine and assembly languages. Inquiry methods into IS require application in areas such as requirements analysis, empirical analysis, and experimentation techniques. The Association of Computing Machinery (ACM), the Association for Information Systems (AIS), the Association of Information Technology Professionals (AITP), the Data Management Association International (DAMA), the Computing Society of the Institute of Electrical and Electronic Engineers (IEEE-CS), the Information 
Information Systems Diverse Origins

Resources Management Association (IRMA), the Information Systems Audit and Control Association (ISACA), and the Office Systems Research Association (OSRA) are all IS professional societies.

\section{Academic Quality Assurance}

Professional organizations have an interest in ensuring that the academic programs advance the profession through teaching and research. Guidance is provided by the professional societies through the publication of model curricula and publication venues for research. Assurance is provided by accreditation.

ABET, Inc., composed of 28 professional and technical societies, is the primary accrediting body for applied science, computing, engineering, and technology programs in the United States. There are over 2,700 programs at 550 universities and colleges accredited by ABET, Inc. (ABET, 2007). The Computing Accreditation Commission (CAC) of ABET, Inc. accredits computing programs including information systems, as well as other computer related disciplines. In the US, accreditation is done by independent organizations, and universities participate on a voluntary basis. The Council for Higher Education Accreditation (CHEA) is the proponent for voluntary accreditation and quality assurance to the US Congress and the US Department of Education (Council for Higher Education Accreditation, 2006). An association of 3,000 degree-granting colleges and universities, it recognizes 60 institutional and programmatic accrediting organizations (Council for Higher Education Accreditation, 2006), including ABET, Inc and the Association to Advance Collegiate Schools of Business (AACSB) (Council for Higher Education Accreditation, 2007). The AACSB is recognized by CHEA to accredit universities with business programs.

AACSB accreditation includes consideration of the institution's information systems program. ABET, Inc. accredits specific programs, while AACSB does not accredit programs (with accounting the only exception), but rather accredits the institution.

The ABET, Inc criteria for accreditation are established in coordination with the relevant professional societies, and in the case of information systems follow closely the IS model curricula developed by the ACM, AIS, AITP, and IEEE-CS professional societies (Scime, 2001). Accreditation requirements exceed simply courses and knowledge gained in information systems. In addition to specifications on curriculum, the accreditation process considers faculty and their research, laboratories and computing facilities, institutional support and financial resources, and institutional facilities. Within the area of curriculum, accreditation requires 15 credit hours in an IS environment, an area of study in which IS theory and techniques can be applied. Also, there are requirements of 30 credit hours in general education, social and ethical issues, and oral and written communications skill components in various courses. In addition, there are required computing courses and science and mathematics requirements (Computing Accreditation Commission, 2006). Because ABET, Inc. specializes in IS program accreditation (as well as other computing, engineering, engineering technology, and applied science programs), ABET, Inc. accredited IS programs are certified as being of high quality.

\section{IS Research}

Research dissemination is critical to the growth of knowledge in any discipline. Because IS has been derived from different disciplines over the last three decades, the IS researcher needs some sort of organizing mechanism to map IS research and its dissemination and to relate its different components. IS researchers can benefit from a framework into which research can be classified and from which potential research hypotheses may be generated. Although there are existing models, they tend to be fairly narrow in scope. With IS having diverse origins and foci, IS researchers may not be cognizant of the various types of research and research venues. 
Consequent of the vast scope of IS literature, several studies have been conducted on IS cumulative research with a focus on specific sub-disciplines such as decision support systems (DSS) (Arnott \& Pervan, 2005), e-commerce (Urbaczewski, Jessup, \& Wheeler, 2002), and heterogeneous and distributed environments (March, Hevner, \& Ram, 2000), while others attempt the entire IS field (e.g. Chua, Cao, Cousins, Mohan, Straub, \& Vaishnavi, 2002; Culnan, 1986; Culnan \& Swanson, 1986; Palvia, Leary, Pinjani, \& Midha, 2004).

Studies show that IS literature can be classified by mapping the IS territory to its vast components (Barki, Rivard, \& Talbot, 1988; Cohen, 1999; Gorry \& Scott-Morton, 1971; Ives, Hamilton, \& Davis, 1980). However, Barki, Rivard, and Talbot (1988) argued that such classification schemes are inefficient as they have the major flaw of being customized to their users and not to the entire IS field.

March and Smith (1995) proposed a two dimensional, four-by-four taxonomy, research activity and research output, that can be used to classify IS literature. The research output dimension consists of constructs, models, methods and instantiations. The research activities dimension is based on design and natural science, which consists of build, evaluate, theorize, and justify. March and Smith argued that the taxonomy is invaluable on the basis that an appropriate framework for IS research lies in the intersection of design and natural sciences. They also added that their framework provides an integrative and comprehensive classification scheme to evaluate IS publishing venues. Hevner, March, Park, and Ram (2004) extended March and Smith's taxonomy by organizing March and Smith's research activities into two paradigms: behavioral science and design science. The behavioral science paradigm is rooted in natural science research methods, which seek to develop and verify theories that explain or predict human or organizational behavior. Design science, on the other hand, is fundamentally a problem solving paradigm, which seeks to extend the boundaries of human and organizational capabilities by creating innovative artifacts and clear guidelines for understanding, executing, and evaluating the research (Hevner \& March, 2003; Hevner et al., 2004).

A disconnect exists between behavioral science and design science research. Business schools tend to emphasize behavioral science. This has led to a call to institute more technology in IS programs (Hardaway, Mathieu, \& Will, 2008). At the same time, there has been in recent years growth in creating schools of technology, separating IS from business and housing it with other computing disciplines (Denning, 2001; Mitchell et al., 2003). In an attempt to effectively categorize engineering research, Newman (1994) proposed a pro forma abstract template, which analyzes Human-Computer Interaction (HCI) research in terms of three different kinds of products: improved modeling techniques, solutions, and tools. His analysis focused on the product of engineering research rather than the conventional emphasis on the researcher's method. He concluded that his pro forma abstracting methodology was efficient for categorizing publications.

Andoh-Baidoo, Baker, Susarapu, and Kasper (2007) used Newman's method of pro forma abstract to classify research articles published in some of the top tier IS journals and the International Conference on Information Systems (ICIS) proceedings over the period 1998-2002 into an updated version of March and Smith's (1995) taxonomy. This taxonomy classifies IS research based on the distinction between design and behavioral science activities as well as multiple research outputs. As a relatively new discipline, there is an interest in how to teach and establish relevance in information systems, as well as computer science (Andriole, 2006). Randolph, Julnes, Sutines, and Lehman (2008) conducted a content analysis of articles in mainstream computer science education journals and conferences. They found articles varying from program descriptions and how-to-teach a topic through anecdotal reviews to behavioral research using statistical methods. 
Information Systems Diverse Origins

We add to the research on IS cumulative study with a specific focus on how the location of the IS program may influence where faculty publish their research. Considering that the point of departure for research on research can influence the result, in this study we begin with the researchers and their location to determine the type of research they conduct and where they publish the results. In this paper, we examine IS research that falls into the professional categories of business, engineering, education, and library science for faculty from ABET accredited information systems programs. We use the term 'school' to mean the administrative unit in which an IS program is housed.

\section{Research Methodology}

This research looks at the publication venues of the faculty in selected information systems programs. Thus the location of the IS program and the emphasis of the venue where the faculty members' research outputs were published are the main focus of the paper. Four specific classifications were used for both program location and venue type: business, engineering, education, and library science.

The research uses a classification methodology. The venues of publication were classified using various guides. Most venues in this study do contain some kind of guide to their content, whether in the form of a Table of Contents (TOC), or a Call for Papers (CFP). Each venue was reviewed

to determine if it is of a more business, engineering, education, or library science orientation. This determination was made by reviewing the content guides (TOCs for books, journals, and conference proceedings, and CFP's for conference and workshop announcements) for the venue's purpose and professional audience from which it was classified into one of the four categories: business, engineering, education and library science.

Our approach is similar to topical content guides, which have been used previously in the Information Systems discipline. For instance, Alavi, Carlson, and Brooke (1989) used keyword analysis of IS journals' TOCs as part of a larger study of IS literature. Content guides have also been used in the field of document analysis, where software algorithms analyze TOCs of literature for the purpose of automated analysis (Belaid, 2001; Kwon \& Park, 2007; Lin \& Xiong, 2006).

The classification system, devised by a reference librarian, uses content analysis as a means of coding items within the taxonomy. Using rules of inference based on the knowledge of coders, the content analysis draws upon the analytical ability of the reader to comprehend key meanings in a piece of text (White \& Marsh, 2006). To properly classify items, the coders analyzed contextual clues designating key concepts such as specific artifacts or methods. This practice of "emergent coding," creating schemes of contextual rules as they are gradually observed during a study, is often used in content analysis studies (Thayer, Evans, McBride, Queen, \& Spyridakis, 2007).

The research methodology consists of two steps. In the first step (data collection) the artifacts published by faculty members were recorded. In step two (data coding), the location of the IS program and the venue where artifacts were published were classified. Detail description of each step is discussed below.

\section{Data Collection}

Research artifact data used in this study was gathered between November 1 and December 15, 2007. This artifact data was collected from the Web sites of faculty in the departments with information system programs accredited by ABET, Inc.

The faculty Web sites of these schools were visited and the publication citation data from each faculty member's posted vita extracted. This collection of citations represents the self-reported 
research having been conducted by the faculty including research articles published in journals, conference proceedings, book chapters, books, and audio and video recordings. For each artifact, specific attributes recorded included the artifact's title, year of publication, venue of publication, as well as the faculty member's name, school name, and program name.

\section{Data Coding}

The location of each IS program and each venue of publication were classified. Two of the authors, a librarian and a graduate student, performed the bulk (95\%) of the venue data coding. The majority of data for coding venue of publication came from three sources: specific journal Web sites, conference Web sites, and book publishing Web sites.

This master list of citations recorded in step one was edited to extract the publication venues and duplicate venues were eliminated. A venue was considered a duplicate if the venue's title was the same. That is, a journal appearing on the list of venues with multiple different issues would be reduced to one entry. The large majority of venues were journals and conferences, with a small minority of books.

From the venue Web sites, TOCs and CFPs were analyzed for approximately $90 \%$ of the items. Occasionally, a serial librarian's research guide, in this case Ulrich's (Bowker, 2006), was used to find information on journals with no Web site presence. These sources of data were chosen for the study because they are both reliable and unbiased.

Prior to the study, coders familiarized themselves with the four information systems research paradigms under consideration. Then, for each venue on the master list, a TOC or a CFP was located and read by one of the coders. Coders then classified each single article title, chapter title, or conference topic within the TOC or CFP into the categories of business, engineering, education, library science or other.

When all titles or topics in the TOC or CFP were completely read and classified, coders designated the entire venue into one category when a majority (approximately $75 \%$ or more) of its articles/chapters/topics fell into one category. Generally, no item contained content exclusively in one category, but most had a clear majority. Coded items that did not apply to one of the four categories in this study were designated as other.

Not all items could be coded. Some items did not have ready sources of information for coding. Other items were in foreign languages and could not be read by coders. Occasionally, items with ambiguous names or unclear citations had to be dropped.

Several measures were taken by coders to ensure the accuracy of the classification system. When possible, coders collected data from two separate issues of a journal to eliminate variance and the chance of a special issue devoted solely to one topic. To calculate inter-rater reliability, the first coder also coded a random sample of 50 items from the second coder's set of items. Of this sample, the consistency between the two coders was $45 / 50$ items for a raw agreement of $90 \%$, which yields a Cohen's Kappa ratio of 0.849 (See Appendix). According to Landis and Koch (1977), a Kappa value of 0.80 is regarded as a substantial agreement between observers.

The ABET, Inc. accredited IS programs were classified according to the type of administrative unit (school or college) in which the program is housed. Programs were considered part of a business school if the school in which the IS program is located also houses traditional business disciplines such as accounting, marketing, and management. Computing schools are those that include other disciplines in which the use of computers is a dominant factor relating the school's departments. Engineering schools also include the traditional engineering disciplines such as mechanical, electrical or civil engineering. Science schools also house programs in chemistry, biology, or 
Information Systems Diverse Origins

physics. Library schools teach and research library science as well as information systems. Technology schools contain programs in things like construction technology and other technologies not primarily related to computing or traditional engineering. Finally, schools of arts and sciences house liberal arts disciplines such as English, History, and the sciences (where there is no separate school for science).

\section{Observations}

For the current study, the publication venues were classified as business, education, engineering or library science. While coding, coders found that the most useful keywords for content analysis in the professional taxonomy (business, education, engineering or library science) were "nouns/things" and not "verbs/actions." Items (tools/artifacts/resources) are more professionspecific than actions, which can be more ambiguous. For example, the action term "optimize" could be used in both engineering ("optimize sensor speed") and business ("optimize employee efficiency"). However, in those examples, the nouns "sensor" and "employee" clearly belong in two different professional categories.

After coding all data, coders informally compared some commonly seen contextual clue words to Barki, Rivard, and Talbot's (1993) updated list of IS keywords and found that most words overlapped. However, there were some notable exceptions that were not found on Barki, Rivard, and Talbot's list. Some examples include the following commonly seen keywords: "XML," "pedagogy," "metadata," "Internet," "digitization," "commerce," "adaptive learning," and "supply chain". This discrepancy is not surprising. For one thing, many technologies related to IS research (and used by coders as clue words) have been designed or have come to prominence after the initial publication of Barki, Rivard, and Talbot's keyword list. Also, many keywords which provided contextual clues to professional taxonomies outside of IS, such as "digitization" (usually denoting library science) or "pedagogy" (usually denoting education), would not be expected to be found on Barki, Rivard, and Talbot's list.

\section{Findings}

When the data were collected there were 24 IS programs accredited by ABET, Inc. Of these 24 programs, 21 had Web sites with citation data of at least one faculty member. These 21 IS programs represent origins from business, engineering, and library science most with a close relationship to computer science. Classification of the 21 programs by type is shown in Table 1 . The arts and sciences school's IS program is in a mathematics, computer science, and information science department. In addition to IS, the computing schools include computer science programs, all of which are also ABET, Inc. accredited. The engineering schools include electrical engineering programs and three engineering schools include computer science. The fourth university places computer science in the college of arts and sciences, while the IS program is titled information systems engineering in the engineering school. The library school, originally just library science, has expanded to information systems (Mitchell et al., 2003). Also in this case, computer science is located in the school of arts and sciences. All the science schools include computer science (also ABET, Inc. accredited) and mathematics, as well as IS. The technology school has both IS and CS

\begin{tabular}{|l|r|}
\hline \multicolumn{2}{|c|}{ Table 1: IS program school types } \\
\hline School Type & $\begin{array}{c}\text { Number of } \\
\text { Programs }\end{array}$ \\
\hline Arts and Sciences & 1 \\
\hline Business & 6 \\
\hline Computing & 5 \\
\hline Engineering & 4 \\
\hline Library & 3 \\
\hline Science & 1 \\
\hline Technology & 3 \\
\hline
\end{tabular}


programs accredited by ABET, Inc. Three of the business schools are also accredited by AACSB.

The faculty reported 4126 artifacts in 2302 different venues of research. Overall, 2224 of the 2302 venues were coded and classified. Table 2 provides the distribution of venues by school type and venue type. Of course, faculty from different schools may publish in the same venues. As a result, the total of the venue types in Table 2 is more than 2224. In one case, two faculty members from different schools co-authored a paper. This paper and its journal were counted twice, once for each school. In cases where co-authors were at the same school the artifact was counted just once.

Additionally, Table 3 is the distribution of the 4126 unique artifacts by school type and venue type. The publication dates of these artifacts range from 1966 to 2008 and in press.

\begin{tabular}{|l|r|r|r|r|r|r|}
\hline \multicolumn{7}{|c|}{ Table 2: Type of school and venue types } \\
\hline \multirow{2}{*}{ School Type } & \multicolumn{7}{|c|}{ Venue Type } \\
\cline { 2 - 7 } & Total & Business & Education & Engineering & Library & \multicolumn{1}{c|}{ Other } \\
\hline Arts and Sciences & 19 & 5 & 2 & 11 & & 1 \\
\hline Business & 350 & 125 & 40 & 169 & & 16 \\
\hline Computing & 791 & 186 & 117 & 412 & 13 & 63 \\
\hline Engineering & 276 & 15 & 33 & 178 & 33 & 17 \\
\hline Library & 670 & 44 & 95 & 386 & 102 & 43 \\
\hline Science & 333 & 42 & 45 & 217 & & 29 \\
\hline Technology & 99 & 14 & 25 & 59 & & 1 \\
\hline
\end{tabular}

\begin{tabular}{|l|r|r|r|r|r|r|}
\hline \multicolumn{7}{|c|}{ Table 3: Type of school and number of artifacts in each venue type } \\
\hline \multirow{2}{*}{ School Type } & \multicolumn{7}{|c|}{ Venue Type } \\
\cline { 2 - 7 } & Total & Business & Education & Engineering & Library & Other \\
\hline Arts and Sciences & 24 & 5 & 2 & 15 & & 2 \\
\hline Business & 604 & 208 & 68 & 305 & & 23 \\
\hline Computing & 1389 & 290 & 188 & 795 & 15 & 101 \\
\hline Engineering & 343 & 18 & 46 & 217 & 41 & 21 \\
\hline Library & 1123 & 52 & 177 & 639 & 197 & 58 \\
\hline Science & 513 & 58 & 78 & 332 & & 45 \\
\hline Technology & 130 & 15 & 41 & 73 & & 1 \\
\hline
\end{tabular}

Because the number of schools in each type varies, an adjustment is made. Tables 4 and 5 provide the count adjusted for the number of schools. As shown in Tables 2-5, irrespective of the school type or the location of the IS program, over $50 \%$ of the published materials are in engineering. 
This finding can be explained by the fact that most IS programs irrespective of their location recognize some of the engineering based journals such as IEEE journals as high quality. Besides engineering oriented journals, we also observe from the data that business school IS programs produced more research in business oriented journals than any other venue. Similarly, faculty from library science IS programs produced more articles in library science oriented journals than any other venue. Hence we can conclude that the location of the IS program influences the research publication venue. For the business schools for instance a possible observation on faculty orientation is that faculty published more behavior science types of research. In addition, because other faculty from the business schools may review their tenure and promotion applications, faculty are motivated to publish in more business-oriented journals. In fact, some IS programs have specific target journals and the list of journals may relate to the location of the IS program. Thus the tenure and promotion requirements influence the venue of publication.

\begin{tabular}{|l|r|r|r|r|r|r|}
\hline \multirow{2}{*}{ Table 4: Type of school and venue types per school basis } \\
\hline \multirow{2}{*}{ School Type } & \multicolumn{7}{|c|}{ Venue Type } \\
\cline { 2 - 7 } & Total & Business & Education & Engineering & Library & Other \\
\hline Arts and Sciences & 19.0 & 5.0 & 2.0 & 11.0 & & 1.0 \\
\hline Business & 58.3 & 20.8 & 6.7 & 28.2 & & 2.7 \\
\hline Computing & 158.2 & 37.2 & 23.4 & 82.4 & 2.6 & 12.6 \\
\hline Engineering & 69.0 & 3.8 & 8.3 & 44.5 & 8.3 & 4.3 \\
\hline Library & 670.0 & 44.0 & 95.0 & 386.0 & 102.0 & 43.0 \\
\hline Science & 111.0 & 14.0 & 15.0 & 72.3 & & 9.7 \\
\hline Technology & 99.0 & 14.0 & 25.0 & 59.0 & & 1.0 \\
\hline
\end{tabular}

Table 5: Type of school and number of artifacts in each venue type per school basis

\begin{tabular}{|l|r|r|r|r|r|r|}
\hline \multirow{2}{*}{\multicolumn{1}{|c|}{ School Type }} & \multicolumn{7}{|c|}{ Venue Type } \\
\cline { 2 - 7 } & Total & Business & Education & Engineering & Library & Other \\
\hline Arts and Sciences & 24.0 & 5.0 & 2.0 & 15.0 & & 2.0 \\
\hline Business & 100.7 & 34.7 & 11.3 & 50.8 & & 3.8 \\
\hline Computing & 277.8 & 58.0 & 37.6 & 159.0 & 3.0 & 20.2 \\
\hline Engineering & 85.8 & 4.5 & 11.5 & 54.3 & 10.3 & 5.3 \\
\hline Library & 1123.0 & 52.0 & 177.0 & 639.0 & 197.0 & 58.0 \\
\hline Science & 171.0 & 19.3 & 26.0 & 110.7 & & 15.0 \\
\hline Technology & 130.0 & 15.0 & 41.0 & 73.0 & & 1.0 \\
\hline
\end{tabular}


The 21 schools have 301 faculty members with citations of artifacts on the school Web site or accessible from the school Web site. Of course, some IS programs are larger than others. Table 6 provides the number of faculty members in each school type. This leads to Tables 7 and 8 , where the venue and artifact counts are based on the number of faculty.

\begin{tabular}{|l|r|}
\hline \multicolumn{2}{|c|}{ Table 6: Faculty count } \\
\hline \multicolumn{1}{|c|}{ School Type } & $\begin{array}{c}\text { Number of } \\
\text { Faculty }\end{array}$ \\
\hline Arts and Sciences & 12 \\
\hline Business & 54 \\
\hline Computing & 59 \\
\hline Engineering & 63 \\
\hline Library & 40 \\
\hline Science & 44 \\
\hline Technology & 29 \\
\hline
\end{tabular}

\begin{tabular}{|l|r|r|r|r|r|r|}
\hline \multicolumn{7}{|c|}{ Table 7: Type of school and venue types per faculty basis } \\
\hline \multirow{2}{*}{ School Type } & \multicolumn{7}{|c|}{ Venue Type } \\
\cline { 2 - 7 } & Total & Business & Education & Engineering & Library & Other \\
\hline Arts and Sciences & 1.6 & 0.4 & 0.2 & 0.9 & & 0.1 \\
\hline Business & 6.5 & 2.3 & 0.7 & 3.1 & & 0.3 \\
\hline Computing & 13.4 & 3.2 & 2.0 & 7.0 & 0.2 & 1.1 \\
\hline Engineering & 4.4 & 0.2 & 0.5 & 2.8 & 0.5 & 0.3 \\
\hline Library & 16.8 & 1.1 & 2.4 & 9.7 & 2.6 & 1.1 \\
\hline Science & 7.6 & 1.0 & 1.0 & 4.9 & & 0.7 \\
\hline Technology & 3.4 & 0.5 & 0.9 & 2.0 & & 0.0 \\
\hline
\end{tabular}

Table 8: Type of school and number of artifacts in each venue type per faculty basis

\begin{tabular}{|l|r|r|r|r|r|r|}
\hline \multirow{2}{*}{\multicolumn{1}{|c|}{ School Type }} & \multicolumn{7}{|c|}{ Venue Type } \\
\cline { 2 - 7 } & Total & Business & Education & Engineering & Library & \multicolumn{1}{c|}{ Other } \\
\hline Arts and Sciences & 2.0 & 0.4 & 0.2 & 1.3 & & 0.2 \\
\hline Business & 11.2 & 3.9 & 1.3 & 5.6 & & 0.4 \\
\hline Computing & 23.5 & 4.9 & 3.2 & 13.5 & 0.3 & 1.7 \\
\hline Engineering & 5.4 & 0.3 & 0.7 & 3.4 & 0.7 & 0.3 \\
\hline Library & 28.1 & 1.3 & 4.4 & 16.0 & 4.9 & 1.5 \\
\hline Science & 11.7 & 1.3 & 1.8 & 7.5 & & 1.0 \\
\hline Technology & 4.5 & 0.5 & 1.4 & 2.5 & & 0.0 \\
\hline
\end{tabular}




\section{Conclusions}

Information systems is a discipline with varying origins. The information system program accreditation agency, ABET, Inc. has approved programs that originated from different disciplines. The researchers in information systems continue to be a diverse group influenced by their reference disciple, whether it is business, engineering, library science, or computer science. The business schools have IS programs that support the business disciplines. Engineering schools apply engineering principles to the IS discipline. Information systems grew from library science at one school independently from business, engineering, and computer science; all programs found in other schools at that university. This library science school has transformed itself into an information systems school. In the arts and sciences, computing, science, and technology schools, IS is located near computer science, which often was derived from mathematics (Scime, 2002).

Other than library and technology schools, publication in education venues is low. This may be a result of less value being placed on how best to teach. The scholarship of teaching is sometimes not recognized by department and school cultures as much as research in information systems (Lynch, Sheard, Carbone, \& Collins, 2005).

These results may be due to the nature of the research and the culture in the computing and library schools. The engineering venues where the computing and library schools are dominant include many more conferences and their proceedings than the business venues. The engineering paradigm is the design and implementation of computer based systems, closely related to computer science. The Computing Research Association (1999) holds that in the field of computer science conference publication is both rigorous and prestigious. This clearly transfers to the engineering aspects of information systems, whereas IS research in business schools has emphasized user attitudes, perceptions, and acceptances at the organizational, group, and user level (Hardaway et al., 2008). Reasons for this may stem from influence from the other business disciplines, school culture, and the need of junior faculty to "fit in" while pursuing tenure. As an information systems researcher one must determine the paradigm in which they work and then look for an IS program that will support that work.

The many compelling reasons for IS faculty to publish professionally include career development, adding value to their institution, and of course intellectual curiosity (Athey \& Plotnicki, 2000). As our data shows, the academic placement of an IS department generally has a strong influence on its most common type of publishing output venue, and IS faculty could use this data to help with their publishing strategies. For example, submitting one's research to an output venue less commonly associated with one's own IS school could have unforeseen benefits. For example, IS research, coming from so many origins, is now being increasingly valued by a number of separate disciplines in both private and public sectors (Baskerville \& Myers, 2002). In addition, an IS faculty member limiting their publication submissions to one particular range of venues might find a better fit and more success within another discipline's set of venues. So, publishing to a wide range of venue outputs should help a faculty member distinguish themselves and find more publishing success.

\section{Limitations and Future Work}

We acknowledge that journals have different quality as per journal rankings which is also related to the acceptance rate of an A journal from a B journal. Thus, the efforts required to publish an article in an A journal is obviously higher than that required for a $\mathrm{B}$ journal. Hence, comparing faculty research output without taking into consideration journal ranking is a limitation of this paper and an opportunity for further work. 
We took cautions in ensuring the validity of the coded data. For instance, we dropped articles with ambiguous titles or unclear citation that were possibly published in interdisciplinary journals in order to avoid subjective categorizations. We dropped articles that could not be coded. Similarly, articles that either did not have ready sources of information for coding or were in foreign languages and could not be read by coders were dropped. Where there was disagreement between the two coders on deciding on the venue type, we met to discuss and agree on a category. While all these precautionary measures were taken to enhance the validity of the methodology, there are situations where there were concerns that the venue does not clearly fit into any of the categories especially for journals that are interdisciplinary in nature. This particular situation is a limitation of the paper.

Data collected for this study was self reported by the schools, programs, and faculty on the Web. Hence, our findings reflect the information that was available to the researchers. This is a major limitation of the study. Directly surveying the faculty and asking about their publications could enhance the validity of the study. The study could also be expanded beyond the ABET, Inc. accredited programs to all IS programs or PhD granting programs.

The dates of artifacts gathered ranged from 1966 to 2008 and in press. It would be interesting to do a temporal analysis of the artifacts to determine changes in IS research during that period. In this work no consideration was taken of the Carnegie classification of the university in which the IS program and school reside. The IS programs in this study are in universities across the Carnegie spectrum. Dividing the results by Carnegie classification may show one paradigm more prominent in one type of university over another.

\section{References}

ABET. (2007). Structure. Retrieved July 15, 2007 from http://www.abet.org/structure.shtml

Alavi, M., Carlson, P., \& Brooke, G. (1989). The ecology of MIS research: A twenty year status review. Proceedings of the Tenth International Conference on Information Systems, 363-375.

Andoh-Baidoo, F. K., Baker, E. W., Susarapu, S. R., \& Kasper, G. M. (2007). A review of IS research activities and outputs using pro forma abstracts. Information Resource Management Journal, 20, 65-79.

Andriole, S. J., (2006). Business technology education in the early 21 st century: The ongoing quest for relevance. Journal of Information Technology Education, 5, 1-12. Retrieved from http://jite.org/documents/Vol5/v5p001-012Andriole36.pdf

Arnott, D., \& Pervan, G. (2005). A critical analysis of decision support systems research. Journal of Information Technology, 20, 67-87.

Association of American Colleges. (1992). Program review and educational quality in the major.

Athey, S., \& Plotnicki, J. (2000). An evaluation of research productivity in academic IT. Communications of the Association for Information Systems, 3(7), 1-19.

Aytes, K., \& Beachboard, J. (2007). Using the information orientation maturity model to increase the effectiveness of the core MBA IS course. Journal of Information Technology Education, 6, 371-385. Retrieved from http://jite.org/documents/Vol6/JITEv6p371-385Aytes262.pdf

Barki, H., Rivard, S., \& Talbot, J. (1988). An information systems keyword classification scheme. MIS Quarterly, 34, 299-322.

Barki, H., Rivard, S., \& Talbot, J. (1993). A keyword classification scheme for IS research literature: An update. MIS Quarterly, 17, 209-226.

Baskerville, R., \& Myers, M. (2002). Information systems as a reference discipline. MIS Quarterly, 26, 114. 
Information Systems Diverse Origins

Belaid, A. (2001). Recognition of table of contents for electronic library consulting. International Journal on Document Analysis and Recognition, 4, 35-45.

Bowker, R. (Ed.). (2006). Ulrich's periodicals directory (44th ed.). New Providence, NJ: R.R. Bowker.

Chua, C., Cao, L., Cousins, K., Mohan, K., Straub, D. W., \& Vaishnavi, V. (2002). IS bibliographic repository (ISBIB): A central repository of research information for the IS community. Communications of the Association for Information Systems, 8, 392-412.

Cohen, E. (1999). From ugly ducking to swan. Journal of Computing and Information Technology, 7, 213219.

Computing Accreditation Commission. (2006). Criteria for accrediting computing programs. Baltimore: ABET, Inc.

Computing Research Association. (1999). Best practices memo evaluating computer scientists and engineers for promotion and tenure. September 1999.

Council for Higher Education Accreditation. (2006). CHEA at a glance. Washington, DC. Retrieved De-

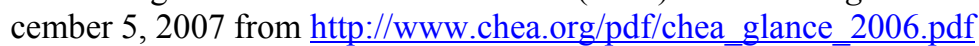

Council for Higher Education Accreditation. (2007). Recognized accrediting organizations. Washington, DC. Retrieved November 30, 2007 from www.chea.org/pdf/CHEA_USDE_AllAccred.pdf

Culnan, M. J. (1986). Mapping the intellectual structure of MIS, 1972-1982: A co-citation analysis. Management Science, 32, 156-172.

Culnan, M. J., \& Swanson, E. B. (1986). Research in management information systems, 1980-1984: Points of work and reference. MIS Quarterly, 10, 289-301.

Davis, G. B., Gorgone, J. T., Couger, J. D., Fienstein D. L., \& Longnecker, H. E. (1997). IS'97 model curriculum and guidelines for undergraduate degree programs in Information Systems. Association of Information Technology Professionals.

Denning, P. J. (1998). Computer science and software engineering: Filing for divorce? Communications of the $A C M, 40(8), 128$.

Denning, P. J. (2001). The IT schools movement. Communications of the ACM, 44(8), 19-22.

Dressel, P. L., \& Marcus, D. (1982). On teaching and learning in college. San Francisco: Jossey-Bass.

Freeman, P., \& Aspray, W. (1999). The supply of information technology workers in the United States. Washington, DC: Computing Research Association.

Gorry, G.A., \& Scott-Morton, M.A. (1971). A framework for management information systems. Sloan Management Review, 13(1), 55-70.

Hardaway, D., Mathieu, R.G., \& Will, R. (2008). A new mission for the information systems discipline. Computer, 41, 81-83.

Hevner, A. R., \& March, S. T. (2003). The information systems research cycle. Computer, 36, 111-113.

Hevner, A. R., March, S. T., Park, J., \& Ram, S. (2004). Design science in information systems research. MIS Quarterly, 28, 75-105.

Information Resources Management Association (IRMA). (1999). IRMA/DAMA curriculum model. Retrieved November 15, 1999 from http://www.irma-international.org/crclm919.html

Ives, B., Hamilton, S., \& Davis, G.B. (1980). A framework for research in computer-based management information systems. Management Science, 26, 910-934.

Kwon, Y., \& Park, J. (2007). Implementation of content analysis system for recognition of journals' table of contents. Proceedings of the Ninth International Conference on Document Analysis and Recognition, 2, 1018-1022. 
Landis, J. R., \& Koch, G. (1977). The measurement of observer agreement for categorical data. Biometrics, $33(1), 159-174$.

Lin, X., \& Xiong, Y. (2006). Detection and analysis of table of contents based on content association. International Journal of Document Analysis, 8, 132-143.

Lindsay, J. (2000). Information Systems - Fundamentals and issues. Retrieved July 26, 2008 from: http://www.oturn.net/isfi/index.html

Lynch, J., Sheard, J., Carbone, A., \& Collins, F. (2005). Individual and organisational factors influencing academics' decisions to pursue the scholarship of teaching ICT. Journal of Information Technology Education, 4, 219-236. Retrieved from http://jite.org/documents/Vol4/v4p219-236Lynch56.pdf

Madnick, S. E. (1992). The challenge: To be part of the solution instead of being part of the problem. In V. Storey \& A. Whinston (Eds.), Proceedings of the Second Annual Workshop on Information Technology and Systems (pp.1-9). Dallas, TX.

March, S. T., \& Smith, G, F. (1995). Design and natural science research on information technology. Decision Support Systems, 15, 251-266.

March, S., Hevner, A., \& Ram, S. (2000). Research commentary: An agenda for information technology research in heterogeneous and distributed environments. Information Systems Research, 11, 327-341.

Mitchell, W., Ford, C., Kraft, D., \& Talburt, J. (2003). What is the difference between information science and computer science? Journal of Computing Sciences in Colleges, 18, 80-83.

Myers, M. E., \& Beise, C. M. (1999). Recruiting IT faculty. Communications of Association for Information Systems, 2(13), 1-29.

Newman, W. (1994). A preliminary analysis of the products of HCI research, using pro forma abstracts. Presented at the Human Factors in Computing Systems Conference, Boston, MA.

Orlikowski, W. J., \& Barley, S. R. (2001). Technology and institutions: What can research on information technology and research on organization learn from each other? MIS Quarterly, 25, 145-165.

Palvia, P., Leary, T., Pinjani, P., \& Midha, V. (2004). A meta-analysis of MIS research. Americas Conference on Information Systems, New York, NY.

Randolph, J., Julnes, G., Sutinen, E., \& Lehman, S. (2008). A methodological review of computer science education research. Journal of Information Technology Education, 7, 135-162. Retrieved from http://jite.org/documents/Vol7/JITEv7p135-162Randolph322.pdf

Scime, A. (2001). Information systems draft accreditation criteria and model curricula. Proceedings of the 18th Annual Information Systems Conference 2001 (ISECON 2001), 18(37). Cincinnati.

Scime, A. (2002). Information systems and computer science model curricula: A comparative look. In A. Saber, S. Saber, \& M. Dadashzadeh, (Eds.), Information technology education in the new millennium, (pp. 146-158). Hershey, PA: IRM Press.

Stark, J. S., \& Lattuca, L. R. (1997). Shaping the college curriculum: Academic plans in action. Needham Heights, MA: Allyn \& Bacon.

Thayer, A., Evans, M., McBride, A., Queen, N., \& Spyridakis, J. (2007). Content analysis as a best practice in technical communication research. Journal of Technical Writing and Communication, 37, 267-279.

Urbaczewski, A., Jessup, L. M., \& Wheeler, B. (2002). Electronic commerce research: A taxonomy and synthesis. Journal of Organizational Computing and Electronic Commerce, 12, 263-305.

Watson, H. J., Taylor, K. P., Higgins G., Kadlec, C., \& Meeks, M. (1999). Leaders assess the current state of the IS academic discipline. Communications of Association for Information Systems, 2(2).

White, M., \& Marsh, E. (2006). Content analysis: A flexible methodology. Library Trends, 55, 22-45. 


\section{Appendix: Kappa Results}

Case Processing Summary

\begin{tabular}{|l|r|r|r|r|r|r|}
\hline \multirow{2}{*}{} & \multicolumn{9}{|c|}{ Cases } \\
\cline { 2 - 8 } & \multicolumn{2}{|c|}{ Valid } & \multicolumn{2}{c|}{ Missing } & \multicolumn{2}{c|}{ Total } \\
\cline { 2 - 8 } & $\mathrm{N}$ & Percent & $\mathrm{N}$ & Percent & $\mathrm{N}$ & Percent \\
\hline RaterA * RaterB & 50 & $100.0 \%$ & 0 & $.0 \%$ & 50 & $100.0 \%$ \\
\hline
\end{tabular}

RaterA * RaterB Crosstabulation

\begin{tabular}{|c|c|c|c|c|c|c|}
\hline & \multicolumn{5}{|c|}{ RaterB } \\
\hline & & Business & Education & Library & Engineering & Total \\
\hline \multirow[t]{5}{*}{ RaterA } & Business & 10 & 0 & 0 & 0 & 10 \\
\hline & Education & 0 & 8 & 1 & 1 & 10 \\
\hline & Library & 1 & 1 & 3 & 1 & 6 \\
\hline & Engineering & 0 & 0 & 0 & 24 & 24 \\
\hline & Total & 11 & 9 & 4 & 26 & 50 \\
\hline
\end{tabular}

Symmetric Measures

\begin{tabular}{|ll|r|r|r|r|}
\hline & & \multicolumn{1}{|c|}{$\begin{array}{c}\text { Asymp. Std. } \\
\text { Value }\end{array}$} & \multicolumn{1}{|c|}{ Error $^{\mathrm{a}}$} & Approx. T $^{\mathrm{b}}$ & Approx. Sig. \\
\hline Measure of Agreement & Kappa & .849 & .062 & 9.601 & .000 \\
& N of Valid Cases & 50 & & & \\
\hline
\end{tabular}

a. Not assuming the null hypothesis.

b. Using the asymptotic standard error assuming the null hypothesis.

\section{Biographies}

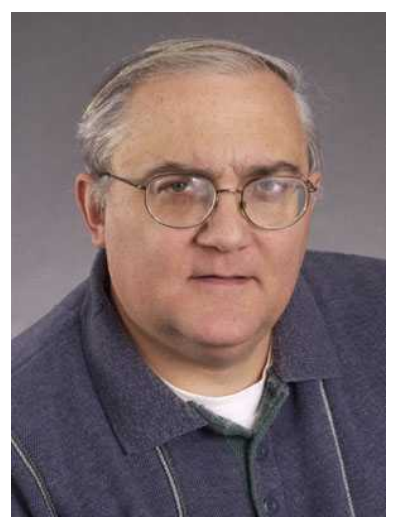

Anthony Scime is a graduate of George Mason University with an interdisciplinary doctorate in Information Systems and Education. Currently he is an Associate Professor of Computer Science at The College at Brockport, State University of New York. Prior to joining academia, he spent over 20 years in industry and government applying information systems to solve large-scale problems. His work has been published in Expert Systems with Applications, Computer Science Education, the International Journal of Business Intelligence and Data Mining, the International Journal of Information and Communication Technology Education, Informing Science, and the Journal of Electronic Commerce Research and Applications. Idea Group Publishing has published his book Web Mining: Applications and Techniques. He is also a member of Editorial Review Boards of the Information Resources Management Journal, and the International Journal of Data Analysis Techniques and Strategies. His research interests include the World Wide Web as an information system and database, information retrieval, knowledge creation and management, decision making from information, data mining and computing education. 


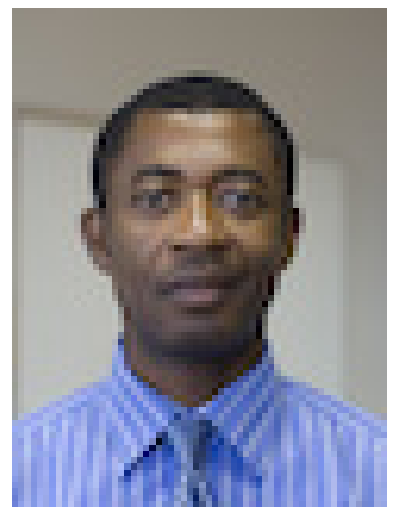

plication.
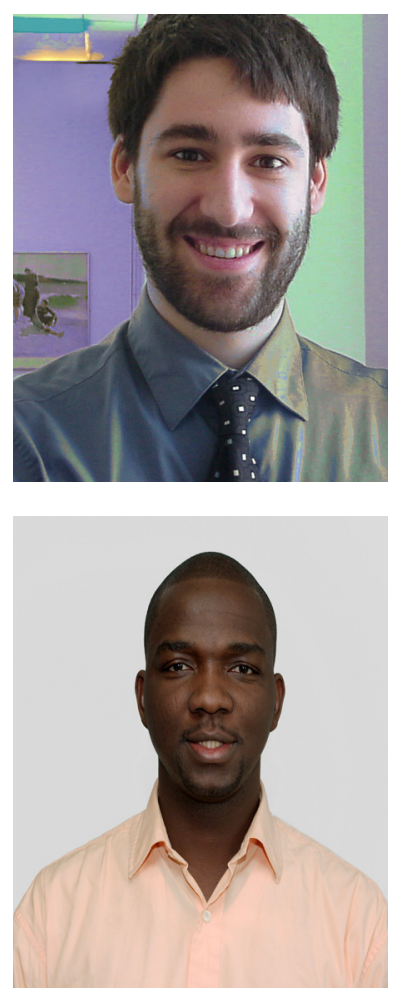
formation Systems, and International Conference on Information Systems. Libraries annual conference.

Francis Kofi Andoh-Baidoo is Assistant Professor, Department of Computer Information Systems and Quantitative Methods, College of Business Administration, University of Texas, Pan American. He has a $\mathrm{PhD}$ in Business Administration with a major in Information Systems and a minor in Finance from the Virginia Commonwealth University in Richmond. His research interests are in data mining, decision support systems, knowledge management, electronic commerce and information security. He serves on the editorial board of four Information Systems Journals. His research has appeared in journals such as Expert Systems with Applications, the Information Resources Management Journal, the Electronic Journal of Information Systems for Developing Countries, and the Journal of Information Technology Theory and Ap-

Charles Bush is a Supervisory Librarian at Drake Memorial Library at The College at Brockport, State University of New York. He received his MS in Library and Information Science, with a Certificate of Advanced Study in Digital Libraries, from Syracuse University. His research interests include digital libraries, mass digitization projects, games in libraries, and Web2.0 applications. He has presented his research at the Eastern New York Association of College and Research

Babajide Osatuyi is pursuing his doctorate degree in Information Systems at New Jersey Institute of Technology in Newark, New Jersey. His research interests are in ontologies, decision support systems, collaborative information foraging, knowledge management, and parallel computing. His research has appeared in journals such as the Electronic Journal of Information Systems for Developing Countries and the International Journal of Innovation and Learning. His research has also appeared in the proceedings of conferences such as the Americas Conference on Information Systems, South Western Decision Support Systems, GROUP Conference, and New Trends in Informatics Research. He has served as a reviewer for the Academy of Management Journal, Computers in Human Behavior,Americas Conference on In- 